\title{
Sistem Usahatani Kopi Arabika Berpelindung sebagai Strategi Konservasi Lahan di Sumatera Utara1
}

\author{
J ef Rudiantho Saragih2 \\ Program Studi Agribisnis, Fakultas Pertanian, Universitas Simalungun \\ J I. Sisingamangaraja, Pematangsiantar 21139, Sumatera Utara \\ email: jefsaragih@ymail.com
}

\begin{abstract}
Deforestation rate in North Sumatra has increased from year to year that causes by addition of critical land and watershed. Meanwhile, forest rehabilitation, reforestation, and social forest development are still face various constraints, thus still less optimal as a strategy to rehabilitation of forest and land. The strategy that can be developed is a shaded and agroforestry arabica coffee farming system. Indonesia was a third largest coffee producer in the world, while North Sumatra is the largest arabica coffee producer in the country. Number of shade tree is still low that is average 54 trees/ ha (standard about 400 trees/ ha). It is required farmers empowerment program concerning the benefit of shade tree to coffee plant. The number of shade tree tends negative effect on arabica coffee production. Therefore premium price through coffee certification program is a prerequisite for land conservation strategy based on shaded and agroforestry coffee farming.
\end{abstract}

Key words: conservation, shaded coffee, agroforestry, certification

\begin{abstract}
Abstrak
Tingkat deforestasi di Sumatera Utara mengalami peningkatan dari tahun ke tahun yang menyebabkan pertambahan luas lahan dan DAS kritis. Sementara itu, upaya rehabilitasi hutan, penghijauan, dan pengembangan hutan rakyat masih menghadapi berbagai kendala sehingga kurang optimal sebagai strategi rehabilitasi hutan dan lahan. Salah satu strategi yang dapat dilakukan adalah sistem usahatani kopi arabika berpelindung dan multistrata. Indonesia merupakan produsen kopi ketiga terbesar di dunia, sementara Sumatera Utara merupakan penghasil kopi arabika terbesar di Indonesia. J umlah pohon pelindung masih sangat rendah yaitu rata-rata 54 pohon/ ha (dengan sistem kopi berpelindung dan multistrata), dari standar ideal jumlah pohon pelindung 400 pohon/ ha. Karena itu, diperlukan program pemberdayaan dan penyadaran petani mengenai manfaat pohon pelindung bagi tanaman kopi. J umlah pohon pelindung cenderung berpengaruh negatif terhadap produksi kopi arabika, sehingga peningkatan harga premium biji kopi melalui program sertifikasi kopi merupakan prasyarat bagi strategi konservasi lahan dan air berbasis usahatani kopi berpelindung dan kopi multistrata.
\end{abstract}

Kata kunci: konservasi, kopi berpelindung, multistrata, sertifikasi

\section{Pendahuluan}

Sebagian besar hutan tropis primer telah beralih fungsi menjadi bentang lahan dengan berbagai tipe pemanfaatan. Tantangan untuk menjaga dan melestarikan keanekaragaman hayati asli hutan mendorong kebutuhan akan sistem pertanian yang mampu mengembangkan dan mengelola keanekaragaman hayati. Penelitian terbaru dan pengalaman petani di berbagai belahan dunia menunjukkan bahwa pola penanaman kopi dengan pohon pelindung memiliki potensi luar biasa bagi pelestarian lahan, tanaman dan hewan tropis, disamping menghasilkan biji kopi berkualitas tinggi (M éndez dan Bacon, 2007).

\footnotetext{
1 Makalah disampaikan pada Sarasehan untuk Peringatan Hari Penanggulangan Degradasi Lahan dan Kekeringan se Dunia, diselenggarakan oleh Forum DAS Asahan-Toba bekerjasama dengan Fakultas Pertanian Universitas Simalungun, Taman Eden 100, Kabupaten Toba Samosir, 17 J uni 2013.

2 Dosen Program Studi Agribisnis Fakultas Pertanian Universitas Simalungun. Pendidikan : S-1 Manajemen Perkebunan USU (1992), S-2 IImu Perencanaan Pembangunan Wilayah dan Perdesaan IPB (1997), S-3 Perencanaan Wilayah USU (2012).
} 
Agroekosistem kopi dengan pohon pelindung berpotensi tinggi memperkuat proses-proses ekologis. Alasannya, dapat dikatakan karena adanya kesamaan struktur antara perkebunan kopi berpelindung dengan ekosistem hutan alami. Proses-proses ekologis seperti siklus nutrisi dan air, aliran energi, dan mekanisme pengaturan populasi berfungsi mirip dengan yang terjadi di hutan tropis. Agroekologi menempatkan pelestarian keanekaragaman hayati sebagai sarana yang bernilai tinggi dalam pengendalian persaingan antartanaman dan pengendalian hama. Pada perkebunan kopi dengan pohon pelindung, sangat penting untuk memahami keanekaragaman hayati pohon yang ada, sebab keberadaan pohon pelindung dapat melipatgandakan tingkat keanekaragaman hayati perkebunan dan lingkungannya (M éndez dan Bacon, 2007).

Sistem multistrata (kopi agroforestri) dengan pohon pelindung merupakan sistem konservasi yang sangat baik. Lapisan tajuk pada sistem multistrata yang menyerupai hutan dapat memberikan fungsi konservasi yang baik dalam mengurangi tingkat erosi tanah. Selain itu, melalui lapisan tajuk, sinar matahari tidak berpengaruh langsung terhadap kopi sehingga kelembaban udara pada kebun kopi dapat terjaga. Tanaman pelindung juga dapat membantu meningkatkan kesuburan tanah. Selain memberikan perlindungan terhadap lingkungan, tanaman pelindung ini dapat meningkatkan ekonomi rumah tangga serta sebagai alternatif dalam mengatasi anjloknya harga kopi. Oleh karena itu, pilihan tanaman untuk sistem multistrata harus disesuaikan dengan kondisi biofisik setempat, komoditas yang dihasilkan harus punya pasar dan petani harus memiliki akses terhadap bibit tanaman yang bermutu tinggi (Mulyoutami et al., 2004). Menurut Prasmatiwi et al. (2004), usahatani kopi berpelindung kompleks (multistrata) lebih berkelanjutan dibanding tipe usahatani yang lain. Kebijakan pemberian izin Hutan Kemasyarakatan $(\mathrm{HKm})$ yang mewajibkan penanaman jenis pohon serbaguna (M ulti Purpose Tree Species, M PTS) minimum 400 pohon/ ha (melalui kebijakan pemerintah daerah) dapat meningkatkan keberlanjutan usahatani kopi.

Selain itu, integrasi tanaman kopi (sektor pertanian) dengan pohon pelindung (sektor kehutanan) dapat meningkatkan keberlanjutan produksi kopi di perdesaan, baik secara ekonomi, sosial, dan ekologi. Secara ekonomi, kopi arabika dapat mendukung keberlajutan karena komoditas ini menjadi komoditas andalan sekaligus komoditas alternatif bagi petani dataran tinggi mengingat rumitnya manajemen usahatani hortikultura selain fluktuasi harga di tingkat petani yang sangat tinggi. Secara sosial, komoditas kopi arabika menjadi keseharian petani dan telah menjadi komoditas yang mampu menghidupkan modal sosial petani mengingat pentingnya kegiatan kolektif dalam usahatani kopi, terutama dalam kegiatan panen dan pemasaran.

Integrasi tanaman kopi dan pohon pelindung dapat mengurangi tingkat kemiskinan di perdesaan sebab menurut Saragih (2012a), usahatani kopi arabika berpelindung di Sumatera Utara mampu memberikan pendapatan setara dengan US\$2,05 per kapita per hari, berada di atas garis kemiskinan Bank Dunia sebesar US\$1,25. Hermawan (2012) menyatakan, sektor pertanian tetap menjadi kunci dan sebagai leading sector dalam mengurangi kemiskinan secara agregat, mengingat kemiskinan terbesar terdapat di perdesaan. Untuk itu, kebijakan pemerintah dalam mengatasi kemiskinan harus fokus dan langsung menuju wilayah-wilayah miskin di perdesaan.

\section{Lahan Kritis}

Penetapan lahan kritis mengacu pada lahan yang telah sangat rusak karena kehilangan penutupan vegetasi, sehingga kehilangan atau berkurang fungsinya sebagai penahan air, pengendali erosi, siklus hara, pengatur iklim mikro dan retensi karbon. Berdasarkan kondisi vegetasinya, kondisi lahan dapat diklasifikasikan sebagai: lahan sangat kritis, kritis, agak kritis, potensial kritis dan kondisi normal. Reboisasi atau rehabilitasi hutan bertujuan untuk menghutankan kembali kawasan hutan yang kritis di wilayah daerah aliran sungai (DAS) yang dilaksanakan bersama masyarakat secara partisipatif.

Kegiatan penghijauan adalah upaya merehabilitasi lahan kritis di luar kawasan hutan melalui kegiatan tanam menanam dan bangunan konservasi tanah agar dapat berfungsi sebagai unsur produksi dan sebagai media pengatur tata air yang baik serta upaya mempertahankan dan 
meningkatkan daya guna lahan sesuai dengan peruntukannya. Pelaksanaan kegiatan penghijauan antara lain berupa kegiatan pembangunan hutan/ kebun rakyat. Kegiatan diarahkan pada lahan masyarakat yang telah terdegradasi di luar kawasan hutan dengan jenis pohon serbaguna, buah-buahan dan tanaman penghasil kayu bakar merupakan tanaman utama.

Sementara pengembangan hutan rakyat dilaksanakan melalui unit-unit usaha. Satu unit usaha merupakan unit pengelolaan usaha hutan tani dengan luas lahan minimal 900 ha. Usaha hutan rakyat dapat dikembangkan pada lahan milik atau lahan yang dibebani hakhak lainnya di luar kawasan hutan yang memenuhi persyaratan untuk kegiatan hutan rakyat. Pada tahun 2011, terdapat 1,1 juta ha lahan kritis di Sumatera U tara, termasuk di dalamnya angka deforestasi tahun 2009/ 2010 sebesar 44.099 ha. Disamping itu, terdapat 59 unit DAS prioritas (43 unit di DAS Asahan Barumun dan 16 unit di DAS Wampu Ular). Sementara itu, pada tahun yang sama, hasil rehabilitasi hutan dan lahan (RHL) masih sangat rendah yaitu sekitar 44.000 ha dengan kecenderungan terjadi penurunan aktivitas RHL sepanjang tahun 2007 sampai 2011 (Kementerian Kehutanan, 2012).

\section{Kopi Indonesia}

Pada tahun 2012/ 2013, Indonesia berada pada peringkat ketiga dalam volume produksi kopi dunia, setelah Brazil dan Vietnam. Volume produksi Indonesia mencapai 764 ribu ton. Produksi kopi Brazil merupakan yang tertinggi yaitu mencapai lebih dari 3 juta ton dan Vietnam sebesar 1,3 juta ton. Sementara pada posisi keempat adalah negara Kolombia (570 ribu ton) $(I C O, 2014)$. Brazil dengan pangsa produksi terbesar $(35 \%)$, sementara Indonesia memasok 9\% (Gambar 1).
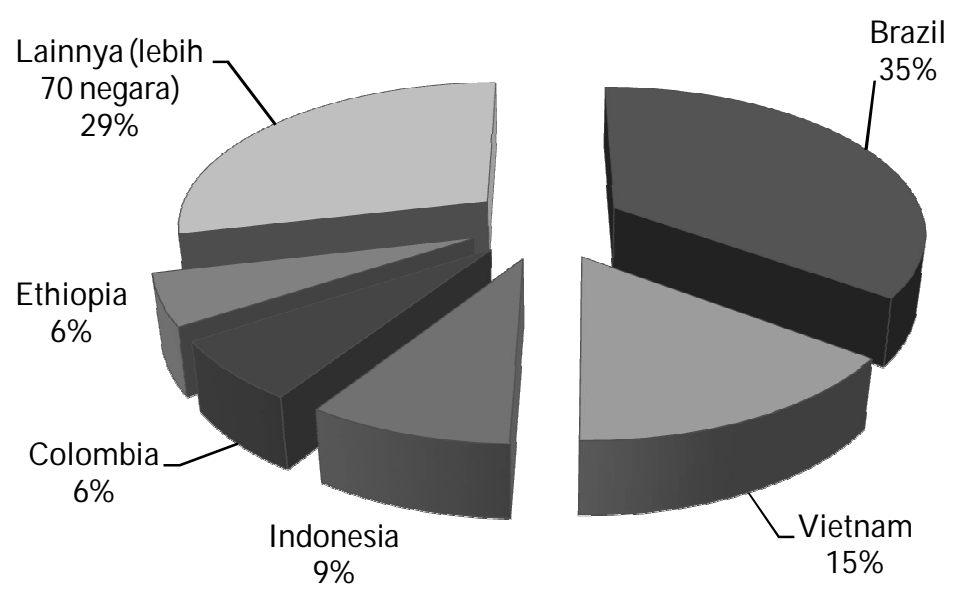

Gambar 1. Pangsa produksi kopi dunia tahun 2012/ 2013

Provinsi Sumatera Utara merupakan produsen terbesar kopi arabika di Indonesia. Produksi tahun 2012 mencapai 48.813 ton. Gambar 2 menunjukkan produksi Sumatera Utara memberikan kontribusi 31\% dari produksi kopi arabika nasional. Posisi kedua ditempati oleh Aceh dengan produksi 47.784 ton (29\%), disusul Sulawesi Selatan dengan produksi 21.279 ton (13\%), Sumatera Barat dengan produksi 14.877 ton (9\%), J awa Timur dengan produksi 8.765 ton (5\%), dan provinsi lainnya dengan pangsa produksi sebesar 13\% (Kementerian Pertanian, 2014).

Luas lahan usahatani kopi arabika di Sumatera Utara mencapai sekitar 60 ribu hektar. Kondisi eksisting pohon pelindung hanya sekitar 54 pohon/ ha. Dengan demikian, terdapat potensi 
penanaman pohon pelindung yang sangat besar pada perkebunan rakyat kopi arabika di Sumatera Utara. J ika dengan asumsi 1.000 hektar saja per tahun dilakukan integrasi tanaman kopi dan pelindung, maka diperlukan penanaman pohon pelindung sejumlah 400 ribu pohon per tahun. Suatu jumlah yang cukup baik dalam rangka konservasi lahan kering di wilayah dataran tinggi Sumatera Utara, terutama di sentra perkebunan kopi arabika. Untuk itu, diperlukan introduksi jenis bibit melalui pembibitan desa, pelatihan manfaat pohon pelindung, serta manajemen pohon pelindung di lahan kopi arabika.

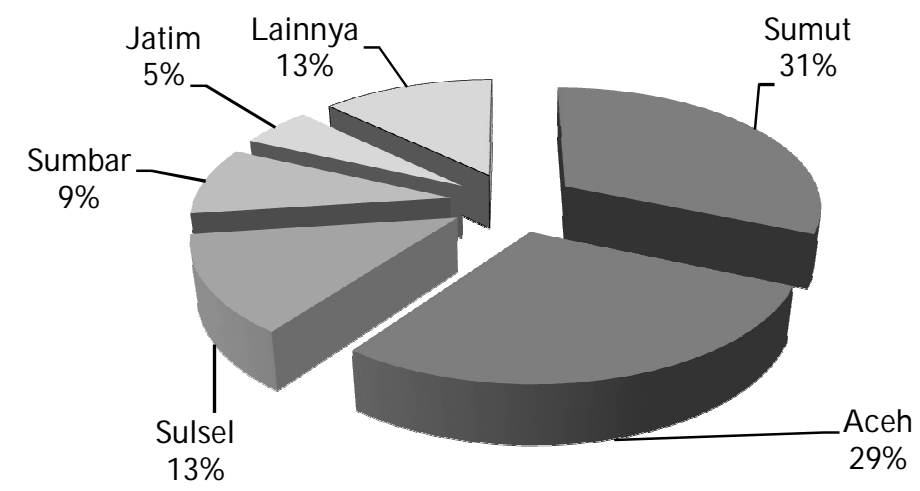

Gambar 2. Pangsa produksi kopi arabika Indonesia tahun 2012

Selain itu, potensi lahan kering di Sumatera Utara masih terbuka luas untuk pengembangan kopi arabika. Sebagai contoh, di Kabupaten Simalungun terdapat potensi lahan kering dan kebun seluas 90 ribu hektar dimana lahan dan iklimnya sesuai untuk perluasan usahatani kopi arabika. Kementerian Pertanian (2010) merekomendasikan penggunaan kopi arabika varietas Sigarar Utang dalam program perluasan areal kopi arabika di Indonesia. Rekomendasi ini didasarkan pada beberapa keunggulan kopi Sigarar Utang, yaitu: (1) sudah diakui dengan keputusan Menteri Pertanian, (2) umur panen pendek, hanya sekitar 18 bulan setelah tanam, (3) tanaman kecil atau kate (dwarf coffee), memungkinkan ditanam dengan populasi banyak, (4) produktivitas relatif tinggi, dan (5) dapat ditanam mulai ketinggian $700 \mathrm{~m}$ di atas permukaan laut. Dari aspek pangsa produksi, kopi arabika Sumatera Utara dipasok dari Kabupaten Dairi sebesar 21\%, disusul Kabupaten Tapanuli Utara (21\%), Simalungun (17\%), Karo (14\%), Humbahas (12\%), dan kabupaten lainnya (Toba Samosir, Samosir, Pakpak Bharat, Deli Serdang, dan Madina) sebesar 15\% (Gambar 3). 


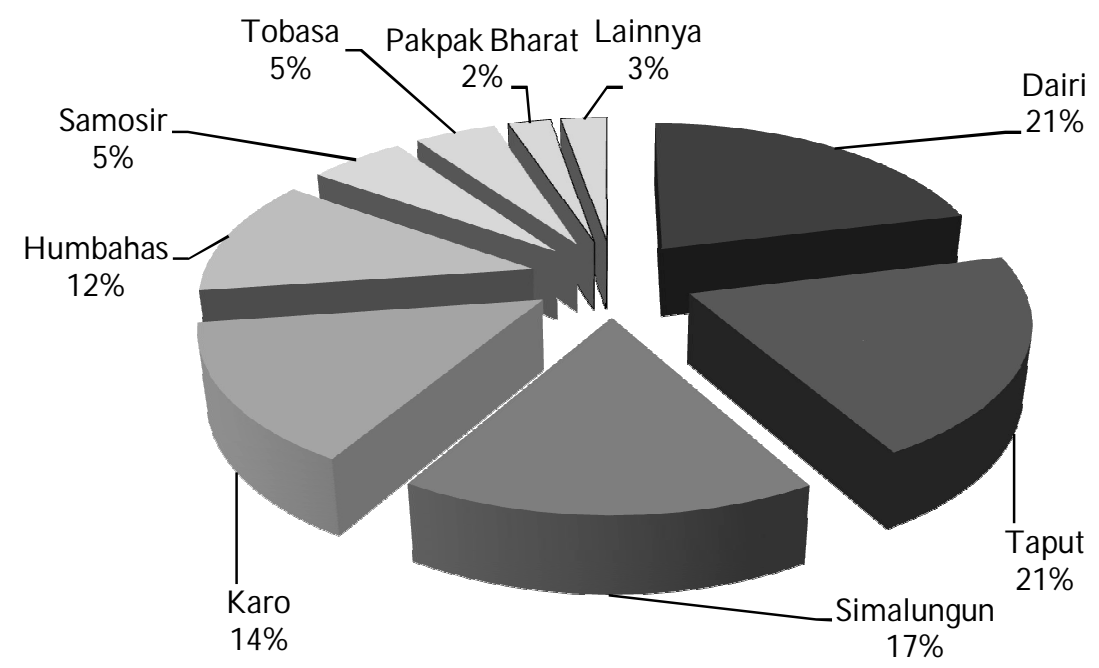

Gambar 3. Pangsa produksi kopi arabika per kabupaten di Sumatera Utara tahun 2011

\section{Ekologi Kopi Arabika Sumatera Utara}

Berkaitan dengan penanggulangan degradasi lahan, kinerja usahatani kopi arabika berpelindung dan praktik konservasi lahan di Sumatera Utara secara umum masih relatif rendah. J umlah pohon pelindung pada usahatani kopi arabika masih jauh dari standar ideal. Di Kabupaten Simalungun rata-rata 67 pohon/ ha, Tapanuli Utara (Taput) 38 pohon/ ha, dan Dairi (55 pohon/ ha) (Tabel 1).

Dengan jumlah pohon pelindung yang relatif rendah tersebut, sebagian petani menerapkan usahatani kopi berpelindung (berturut-turut untuk ketiga wilayah sebesar 18\%, $25 \%$, dan $53 \%$ ) dan sistem multistrata atau agroforestri (14\%, 15\%, dan $15 \%)$. Terdapat empat jenis sistem usahatani yang dilakukan petani dalam budidaya kopi arabika spesialti di Sumatera Utara, yaitu kopi monokultur (sun-coffee), tumpangsari (intercropping), kopi dengan pelindung (simple shade coffee), dan multistrata (multistrata shade coffee). Simple shade coffee adalah sistem usahatani kopi dengan pohon pelindung, tanpa tanaman tumpangsari; sementara sistem multistrata adalah kopi ditanam di bawah pohon pelindung serta bercampur dengan beberapa tanaman lain yang memberikan hasil seperti tanaman buahbuahan, sayuran, kacang-kacangan, dan tanaman obat-obatan (Verbist et al., 2004).

Tabel 1. Karakteristik ekologis usahatani kopi arabika di Sumatera Utara

\begin{tabular}{lllrrr}
\hline No. & Karakteristik ekologis & Satuan & Kab. Simalungun** & Kab. Dairi*** & $\begin{array}{c}\text { Kab. } \\
\text { Taput*** }\end{array}$ \\
\hline 1. J umlah tanaman kopi & pohon/ ha & 2.194 & 1.544 & 1.169 \\
2. & Produkstivitas* & $\mathrm{kg} /$ ha/ tahun & $2.299(951)$ & $1.212(501)$ & $1.440(596)$ \\
3. & Praktik konservasi lahan: & & 60 & 72 & 73 \\
& - Mulsa & 90 & 92 & 95 \\
& - Rorak & $\%$ & 4 & 5 & 2 \\
& - Teras indivisu & $\%$ & 5 & 2 & 2 \\
- Teras bangku & $\%$ & 1 & 1 & 1 \\
4. Jumlah pohon pelindung & pohon/ ha & 67 & 55 & 38 \\
5. Kopi monokultur & $\%$ & 35 & 22 & 32 \\
6. Tumpangsari & $\%$ & 33 & 10 & 28 \\
7. Kopi berpelindung & $\%$ & 18 & 53 & 25 \\
8. Multistrata & $\%$ & 14 & 15 & 15 \\
\hline
\end{tabular}

Keterangan: *Produktivitas dalam wujud kopi tanduk (parchment), angka dalam kurung setara dengan bobot kopi biji (green coffee); TS = tanaman semusim, PP = pohon pelindung, **Saragih (2012b, 2013), ***hasil survei IFC (2011) 


\section{Manfaat Pohon Pelindung}

Pohon pelindung juga mempunyai pengaruh positif secara ekologis. Pelindung meningkatkan siklus nutrisi dengan menyerap nutrisi melalui akar-akarnya yang berada di dalam tanah dan selanjutnya dikembalikan lagi ke tanah melalui tumpukan daun keringnya yang membusuk di permukaan tanah. Pohon pelindung juga mengurangi pertumbuhan gulma, meningkatkan keanekaragaman hayati lokal dengan menyediakan makanan atau naungan bagi banyak spesies lain, seperti burung dan serangga (M endez dan Bacon, 2007).

Beberapa fungsi konservasi yang diberikan oleh tanaman pelindung menurut pendapat petani di Lampung adalah: (1) memberikan naungan. Pada sistem agroforestri kopi dengan naungan kompleks atau multistrata, lapisan tajuk yang menyerupai hutan berfungsi memberikan naungan terhadap kopi dan melindungi permukaan tanah dari terpaan air hujan; (2) menjaga suhu, kelembaban udara dan kelembaban tanah di sekitar kebun. Lapisan tajuk dari pohon pelindung dan serasah yang jatuh dapat mengurangi masuknya cahaya matahari ke dalam kebun dan tanah sehingga suhu, kelembaban udara dan kelembaban tanah di sekitar kebun tetap terjaga.

Akar-akar pohon naungan juga dapat menyimpan air sehingga dapat menjaga kelembaban tanah dan ketersediaan air tanah; (3) menambah kandungan hara dalam tanah. J ika pemilihan tanaman pelindung tepat, misalnya jenis tanaman yang dapat hidup bersama dengan kopi, maka tanaman pelindung dapat menambah kandungan hara dalam tanah melalui serasah daun-daunnya; (4) mengurangi kemungkinan terjadinya erosi dan tanah longsor. Akar pohon pelindung dapat mengikat tanah sehingga tidak terjadi erosi dan tanah longsor; (5) memberikan penghasilan tambahan. Tanaman pelindung dapat memberikan nilai ekonomis bagi petani (Mulyoutami el al., 2004).

Bote dan Struik (2011) pada penelitiannya di Ethiopia menyimpulkan, tanaman kopi yang tumbuh dengan pohon pelindung menghasilkan produksi lebih tinggi dan bobot buah lebih berat dengan kualitas biji lebih baik (better cup taste) daripada kopi yang ditanam tanpa pohon pelindung. Selain itu, pohon pelindung memiliki potensi fisiologis dan biokimia yang lebih besar untuk menghasilkan bahan kering untuk memelihara produksi kopi dalam ujangka panjang. Tambahan pula, kebun kopi dengan pohon pelindung akan memberikan sumber pendapatan lain seperti buahbuahan, kayu bakar, dan kayu komersial, sehingga secara sosial lebih diterima, secara ekonomi lebih menguntungkan, dan secara lingkungan lebih lestari.

Peran pohon pelindung bagi tanaman kopi juga diidentifikasi Vossen (2005) dari berbagai sumber. Dampak positif pohon pelindung bagi tanaman kopi adalah: mengurangi temperatur tanah dan udara ekstrim tinggi (elevasi rendah) dan ektrim rendah (elevasi tinggi), menahan kekuatan angin dan hujan lebat, mengendalikan erosi pada lahan miring, mengendalikan pertumbuhan gulma, menghasilkan 5-15 ton bahan organik (bobot kering) per ha per tahun dari sisa tanaman dan pemangkasan, mendaur ulang hara tanah yang tidak tersedia bagi tanaman kopi dan mengurangi pencucian hara, mencegah pembuahan yang berlebihan dan mati pucuk akibat pengurangan intensitas cahaya, memberikan tambahan penerimaan dari pohon pelindung (papan, kayu bakar, dan buah-buahan), berpotensi mengurangi penyakit hawar daun dan hama white stem borer, memperbaiki cup quality (terutama di wilayah kopi suboptimal secara ekologi akibat temperatur tinggi).

Penelitian mengenai pohon pelindung pada umumnya menunjukkan peran positif sistem multistrata pada tanaman kopi. Dariah et al. (2008) menyimpulkan bahwa usahatani kopi sistem campuran (multistrata) memberikan pengaruh yang lebih baik terhadap kualitas tanah dibandingkan dengan sistem monokultur. Evizal (2009) menemukan berbagai layanan lingkungan yang diberikan oleh pohon pelindung, yaitu: produksi serasah, mengurangi gugur daun kopi, dan menekan pertumbuhan gulma. Produksi serasah sangat penting menyumbang unsur hara tanah terutama Nitrogen. Sumbangan Nitrogen mencapai $66 \mathrm{~kg} / \mathrm{ha}$ (pelindung cempaka), $61 \mathrm{~kg} / \mathrm{ha}$ (gamal), dan $120 \mathrm{~kg} / \mathrm{ha}$ (dadap). Penelitian Erwiyono (2008) menunjukkan bahwa penaung lamtoro paling baik dalam meningkatkan kadar bahan organik tanah, sementara penaung kayukayuan industri (jati, sengon, mindi, waru gunung) lebih baik meningkatkan kadar hara mineral tanah. 
Vossen (2005) menyatakan bahwa pohon pelindung berfungsi sebagai pencegah terjadinya over-bearing karena pengurangan intensitas cahaya dan mencegah tanaman mati pucuk sehingga masa produktifnya lebih panjang. Winaryo et al. (1987) menemukan populasi penaung per hektar yang lebih sedikit dapat meningkatkan daya regenerasi batang dan pertumbuhan tanaman kopi yang lebih baik.

Perluasan areal yang baru perlu ditanam pohon pelindung tanaman kopi. Rekomendasinya adalah: (1) minimal 70 pohon/ ha untuk pelindung non-pangkas (misalnya petai, jengkol, durian, suren, pohon afrika (Maesopsis eminii), alpukat, atau jenis MPTS [multi-purpose tree species] lainnya), atau (2) 400 pohon/ ha untuk pelindung dipangkas (lamtoro/ Leucaena sp, sengon unggul/ Albizia sp, gamal, atau jenis lainnya). Rekomendasi pertama lebih baik digunakan pada kebun kopi sistem tumpangsasi dengan tanaman semusim (multistrata), sementara rekomendasi kedua lebih baik digunakan pada kebun kopi dengan pohon pelindung (simple shade coffee). Kajian tentang sistem kopi naungan atau multistrata melalui program Hutan Kemasyarakatan $(\mathrm{HKm})$ di Lampung Barat (Prasmatiwi et al., 2010) dapat dijadikan rujukan. Pemerintah Daerah memberikan hak penguasaan lahan dalam bentuk izin kelola $\mathrm{HKm}$ atas areal yang selama ini telah dikelola masyarakat. Melalui program $\mathrm{HKm}$, masyarakat mengintegrasikan berbagai jenis tanaman kayu dan tanaman nonkayu (MPTS) serta tanaman setahun dengan prinsip konservasi. Program ini diatur dengan Keputusan Bupati yang mewajibkan anggota kelompok HKm menanam minimal 400 pohon per hektar jenis kayu dan buah selain tanaman kopi. Untuk Kabupaten Simalungun, Komisi Penyuluhan Pertanian, Perikanan, dan Kehutanan Kabupaten Simalungun (2009) pernah memberikan rekomendasi agar permintaan bibit kopi arabika dari Dinas Perkebunan mempersyaratkan penanaman bibit tanaman hutan sebagai pohon pelindung dari Dinas Kehutanan.

Salah satu kelemahan mendasar pada usahatani kopi arabika di wilayah penelitian ini adalah jumlah pohon pelindung masih sangat sedikit. Pohon pelindung yang digunakan oleh petani kopi arabika di Kabupaten Simalungun antara lain adalah dadap (Erythrina lithosfera), suren (Tona sinensis), petai (Parkia spiciosa), jengkol atau jering (Pithecollobium jiringa), sengon (Paraserianthes falcataria), durian (Durio zibethinus), dan alpukat (Parsea gratissima). J ika dibandingkan dengan kriteria umum jumlah pelindung minimal untuk tanaman kopi varietas Sigarar utang yaitu 400 pohon/ ha (Zaenudin 2009) untuk jenis lamtoro (Leucaena glauca) atau gamal (Glirisidia sepium) atau 200-300 pohon/ ha (Mawardi et al., 2008); maka jumlah populasi pohon pelindung pada kebun kopi di Kabupaten Simalungun masih sangat rendah dan perlu ditingkatkan.

J umlah pohon pelindung yang masih sedikit pada usahatani kopi arabika spesialti di wilayah penelitian ini tidak terlepas dari pandangan petani tentang manfaat pohon pelindung. Sebagian besar petani (40\%) belum mengetahui manfaat pohon pelindung bagi tanaman kopi dan konservasi lahan. Sebagian petani $(16 \%)$ menyatakan manfaat pohon pelindung untuk menaungi tanaman kopi dari sinar matahari langsung, 12\% untuk pelestarian lingkungan/ konservasi lahan, dan $4 \%$ bermanfaat ganda sebagai penahan sinar matahari dan angin, mengurangi serangan hama dan penyakit, dan meningkatkan kualitas kopi (Gambar 5).

Gambar 5 menunjukkan bahwa 40\% petani belum mengetahui manfaat pohon pelindung, bahkan $10 \%$ menyatakan pohon pelindung tidak bermanfaat. Hal ini berarti bahwa $50 \%$ petani kopi arabika belum mengetahui manfaat pohon pelindung untuk konservasi lahan dan keberlanjutan produksi. Oleh karena itu, diperlukan program berkelanjutan untuk memberikan pemahaman bagi petani akan pentingnya pohon pelindung, terutama dalam aspek ekologi. Upaya yang dapat dilakukan adalah meningkatkan partisipasi petani dalam perencanaan dan evaluasi program hutan masyarakat. Program yang diintroduksi sebaiknya dapat mendorong petani untuk lebih aktif terlibat dalam perencanaan dan evaluasi. Caranya adalah dengan pendekatan persuasif kepada petani agar petani lebih sering menghadiri pertemuan kelompok. Dalam pertemuan kelompok dapat disampaikan materi yang dapat memotivasi petani untuk lebih aktif terlibat dalam perencanaan dan evaluasi program (Winata dan Yuliana, 2012). 


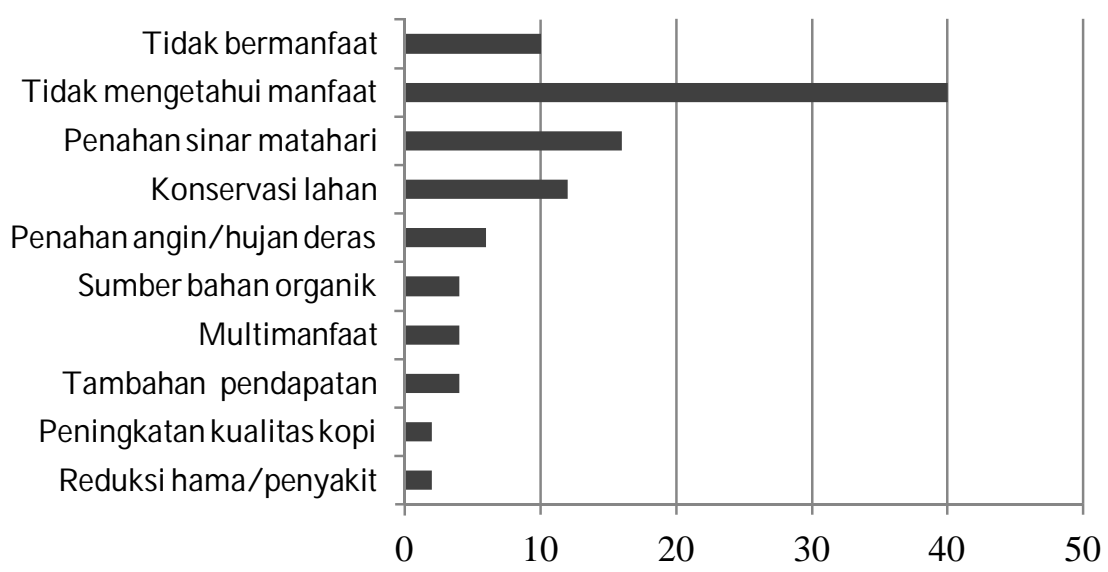

Gambar 5. Manfaat pohon pelindung menurut pandangan petani

Kajian Mulyoutami et al. (2004) mengenai pengetahuan lokal petani dan inovasi ekologi dalam konservasi lahan pertanian berbasis kopi di Lampung Barat menemukan bahwa fungsi konservasi tanaman pelindung adalah: (1) memberikan naungan terhadap kopi dan melindungi permukaan tanah dari terpaan air hujan, (2) menjaga suhu, kelembaban udara dan kelembaban tanah di sekitar kebun, (3) menambah kandungan hara dalam tanah, (4) mengurangi kemungkinan terjadinya erosi dan tanah, dan (5) memberikan penghasilan tambahan.

\section{Pengaruh Pohon Pelindung terhadap Produksi Kopi Arabika}

Dengan menggunakan persamaan regresi majemuk (multiple regression model) ditemukan bahwa jumlah pohon pelindung berpengaruh negatif dan tidak signifikan terhadap produksi kopi arabika (Tabel 2). Hasil ini menunjukkan bahwa semakin banyak populasi pohon pelindung pada tanaman kopi arabika cenderung menurunkan produksi kopi arabika. J umlah populasi pohon pelindung yang semakin banyak mengakibatkan penurunan intensitas cahaya sehingga mengurangi proses fotosintesis yang akan mengakibatkan penurunan produksi. Sama seperti pohon pelindung, penggunaan pupuk organik juga berpengaruh negatif dan tidak signifikan terhadap produksi. Variabel ekologi lainnya (pemangkasan tanaman kopi, konservasi lahan, dan pengendalian PBKo) memeberikan pengaruh positif bagi peningkatan produksi kopi arabika.

Pengaruh negatif yang ditunjukkan dua variabel pertama memberikan implikasi bahwa penerapan sistem usahatani kopi berpelindung dan kopi agroforestri (multistrata) harus sejalan dengan upaya peningkatan harga premium melalui sertifikasi kopi berbasis kelembagaan petani. Dengan kata lain, strategi konservasi lahan dengan kopi berpelindung dan kopi agroforestri ini dapat menjadi insentif bagi petani apabila penurunan produksi dapat dikompensasi dengan harga premium biji kopi di tingkat petani. 
Tabel 2. Pengaruh variabel ekologis terhadap produksi kopi arabika

\begin{tabular}{lrrrc}
\hline Variabel & Koefisien regresi & Standard error & t-hitung & p-value (sig.) \\
\hline Pohon pelindung & $-2,07$ & 1,140 & $-1,815$ & $-0,071$ \\
Pupuk organik & $-2,81$ & 1,611 & $-1,746$ & $-0,082$ \\
Pemangkasan tanaman kopi & $352,61 * * *$ & 105,925 & 3,329 & 0,001 \\
Konservasi lahan & 30,02 & 76,974 & 0,390 & 0,697 \\
Pengendalian PBKo & $221,73^{* *}$ & 92,629 & 2,394 & 0,017 \\
\hline
\end{tabular}

Keterangan: $* *$ dan $* * *$ menunjukkan variabel bebas berpengaruh signifikan terhadap produksi pada $\alpha=5 \%$ dan $1 \%$

Vossen (2005) menyatakan bahwa pohon pelindung berfungsi sebagai pencegah terjadinya over-bearing karena pengurangan intensitas cahaya. Disamping itu, pohon pelindung juga mencegah tanaman mati pucuk (shoot dieback) sehingga masa produktifnya lebih panjang. Sejalan dengan hasil penelitian ini, Winaryo et al. (1987) menemukan bahwa populasi penaung yang lebih sedikit dapat meningkatkan daya regenerasi batang dan pertumbuhan tanaman kopi lebih baik.

Lebih lanjut Vossen (2005) menyatakan beberapa dampak negatif pohon pelindung, yaitu jika populasi pelindung meningkat maka produksi menurun karena proses pembungaan berkurang; kompetisi penggunaan air antara pelindung dan tanaman kopi pada saat musim kering; peningkatan biaya tenaga kerja untuk memangkas pohon pelindung, berpotensi meningkatkan hama dan penyakit, misalnya PBKo. Namun demikian, pohon pelindung berperan positif dalam meningkatkan kualitas kopi seduh (cup quality). Peran positif pohon pelindung dalam kualitas kopi juga ditemukan oleh Yadessa et al. (2008) yang menyatakan bahwa spesies pohon pelindung berpengaruh signifikan terhadap kualitas kopi yaitu acidity, flavour, aftertaste, dan kualitas cup secara keseluruhan. Penelitian Moreira et al. (2008) di wilayah produsen kopi arabika terbesar di dunia di Selatan negara bagian M inas Gerais, Brazil, menyimpulkan bahwa terdapat kecenderungan kualitas kopi yang lebih baik pada sistem usahatani kopi berpelindung.

Penelitian mengenai hubungan antara karakteristik ekologi pohon pelindung dengan produksi kopi di negara bagian Chiapas-M eksiko menemukan bahwa kultivar kopi, umur tanaman, pengayaan spesies, populasi pohon pelindung, dan kemiringan lahan, menunjukkan pengaruh yang tidak signifikan terhadap produksi kopi. Tutupan pohon pelindung 23-38\% memberikan pengaruh positif terhadap produksi kopi, sementara tutupan di atas $50 \%$ dapat menurunkan produksi kopi (Soto-Pinto et al., 2000).

Moreira et al. (2008) menyatakan bahwa meskipun kopi berpelindung diyakini memberikan keragaman hayati yang lebih baik, sistem ini kurang diadopsi karena memberikan produktivitas yang lebih rendah. Sistem yang diterapkan umumnya adalah usahatani kopi konvensional dan usahatani kopi organik tanpa pohon pelindung. Elevitch et al. (2009) menganalisis hubungan antara pohon pelindung dan produksi kopi dengan kesimpulan tidak ditemukan perbedaan yang signifikan dalam produksi kopi untuk empat jenis pelindung kopi pada tingkat naungan di bawah $40 \%$. Tingkat naungan yang lebih tinggi akan menurunkan produksi kopi. Pohon pelindung secara umum meningkatkan ukuran buah matang dan biji kopi karena pohon pelindung mengurangi temperatur udara dan permukaan tanaman. Proses pematangan biji yang lebih lama menghasilkan buah yang lebih besar, dan mengurangi evapotranspirasi.

Meskipun kopi dikembangkan sebagai sistem agroforestri, secara umum dipahami bahwa produksi maksimum diperoleh dengan sistem monokultur yang dikombinasikan dengan pemupukan intensif dan pengendalian gulma. Pohon pelindung mengurangi ketersediaan cahaya untuk fotosintesis, tetapi juga mengurangi stress panas dan penggunaan air. Karenanya, pohon pelindung memiliki manfaat positif dalam kondisi temperatur tinggi, intensitas cahaya tingi, curah hujan rendah, dan tingkat kesuburan tanah rendah.

Verbist et al. (2004) menyatakan bahwa budidaya kopi monokultur biasanya dikelola secara intensif (tingkat aplikasi pupuk dan penyiangan gulma yang tinggi). Sistem budidaya 
ini memang memberikan produktivitas yang lebih baik, akan tetapi sekaligus juga menguras hara tanah dengan cepat, sehingga jika tidak diberikan tambahan asupan hara dari luar berupa pupuk kimia, maka masa produksi kopi yang tinggi akan menjadi lebih singkat dan produksi akan rendah. Bote dan Struik (2011) meneliti peran pohon pelindung terhadap produksi kopi arabika di Ethiopia, yang menemukan bahwa tidak ada perbedaan produksi yang signifikan antara kopi berpelindung dan kopi tanpa pelindung. Meskipun tidak signifikan, produksi kopi biji pada kopi tanpa pelindung lebih tinggi daripada kopi berpelindung.

Berkaitan dengan pohon pelindung dan pupuk organik, berbagai kajian menemukan bahwa pengaruhnya kedua variabel lebih ditujukan untuk produksi kopi berkelanjutan, yaitu memeroleh masa produktif yang lebih panjang. Data produksi kopi dari Chiapas-Meksiko pada tahun 2010 (Arief et al., 2011) dapat dijadikan rujukan. Tanaman kopi dengan pohon pelindung atau kopi yang tumbuh di bawah tutupan hutan menghasilkan $368 \mathrm{~kg} / \mathrm{ha} /$ tahun. Kopi organik dengan pohon pelindung yang tumbuh di bawah tutupan hutan menghasilkan $690-920 \mathrm{~kg} / \mathrm{ha} /$ tahun. Tanaman kopi yang dikelola secara intensif, dengan input kimia, tanpa pohon pelindung, menghasilkan $920-1.610 \mathrm{~kg} / \mathrm{ha} /$ tahun. Oleh karenanya, petani perlu menerapkan praktik produksi kopi berkelanjutan dengan menananm pohon pelindung dan aplikasi pupuk organik. Arief et al. (2011) menyatakan produksi kopi lestari sebagai budidaya kopi konservasi. Karena produktivitas kopi konservasi relatif lebih rendah, maka perdagangan yang adil dan menguntungkan petani perlu ditata, antara lain melalui harga premium, pembayaran jasa lingkungan, dan skema perdagangan karbon kopi.

Manfaat ekologis usahatani kopi dengan tanaman pelindung antara lain adalah konservasi tanah dan air, pengendalian hama dan penyakit, dan antisipasi perubahan iklim (climate change). Di Indonesia, kebun kopi dengan pohon pelindung sistem lorong (alley cropping) mampu mengurangi erosi tanah sebesar 64\% dibandingkan dengan kebun kopi tanpa pohon pelindung. Di Nikaragua, kehilangan tanah pada usahatani kopi tanpa pelindung 2,5 kali lebih besar dibandingkan dengan usahatani kopi berpelindung pada tingkat kemiringan yang sama (Rice, 2010).

\section{Kesimpulan}

Laju deforestasi yang semakin tidak terkendali menjadi peringatan bagi pengelola hutan dan sumberdaya lahan di Indonesia. Pertambahan lahan kritis di berbagai wilayah menjadi tanda masalah lingkungan dan pangan yang semakin serius di masa yang akan datang. Pada sisi lain, upaya-upaya rehabilitasi hutan dan lahan kelihatannya belum menunjukkan hasil yang memuaskan. Kegiatan eksploitasi hutan dan lahan sangat cepat bila dibandingkan dengan upaya-upaya rehabilitasinya. Oleh karena itu, diperlukan upaya yang benar-benar mengundang partisipasi masyarakat untuk mengatasinya. Sebagai komoditas unggulan, integrasi usahatani kopi arabika dengan pohon dinilai sebagai strategi yang dapat dilakukan dalam upaya mengonservasi lahan, terutama di wilayah dataran tinggi. Sistem usahatani kopi yang dikembangkan terintegrasi dengan tanaman hutan atau MPTS, yaitu kopi berpelindung (shade-coffee) dan kopi multistrata (agroforestri).

Namun secara umum, tingkat adopsi petani atas sistem usahatani tersebut dinilai belum seperti yang diharapkan. Karenanya, diperlukan program pemberdayaan petani dan kemitraan multipihak untuk meningkatkan tingkat partisipasi masyarakat mengadopsi sistem usahatani kopi berpelindung dan multistrata. Introduksi sistem ini kepada masyarakat sebaiknya diintegrasikan dengan informasi manfaat pohon pelindung dan penerapan harga premium biji kopi dalam program sertifikasi kopi berbasis kelembagaan petani.

\section{Daftar Pustaka}

Agus, F., Gintings, A.N. dan Noordwijk, M. (2002). Pilihan teknologi agroforestri/ konservasi tanah untuk areal pertanian berbasis kopi di Sumberjaya, Lampung Barat, Internationa Centre for Research in Agroforestry (ICRAF).

Arief, M. C. W., Tarigan, M, Saragih, R. dan Rahmadani (2011). Panduan sekolah lapangan budidaya kopi konservasi: berbagi pengalaman dari Kabupaten Dairi Provinsi Sumatera Utara. Jakarta: Conservation International Indonesia. 
Bote, A. D. and Struik, P.C. (2011). Effects of shade on growth, production and quality of coffee (Coffea arabica) in Ethiopia, J ournal of H orticulture and Forestry Vol. 3, No. 11, pp. 336-341 .

Direktorat J enderal Perkebunan. (2012). Luas areal dan produksi perkebunan seluruh Indonesia menurut provinsi dan status pengusahaan: komoditas kopi. (http:/ / www.ditjenbun. go.id) diunduh pada $4 \mathrm{~J}$ anuari 2013

Direktorat J enderal Perkebunan. (2011). Menteri Pertanian: peranan perkebunan tetap penting, Direktorat J enderal Perkebunan. (http:/ / www. ditjenbun.deptan.go.id) diunduh pada $9 \mathrm{~J}$ anuari 2012

Elevitch, C., Idol, T, Friday, J .B., Lepczyk, C., Smith, V.E., and Nelson, S.C. (2009). Shade-grown coffee for Hawai'i: results of a twelve farm study in Kona, Permanent Agriculture Resources (PAR), Holualoa, Hawaii. (http:/ / www.agroforestry.net/ caf) diunduh pada 17 Maret 2012

Hermawan, I. (2012). Analisis eksistensi sektor pertanian terhadap pengurangan kemiskinan di pedesaan dan perkotaan, MIM BAR: J urnal Sosial dan Pembangunan, Vol. 28, No. 2, pp. 135-144, Bandung: P2U LPPM Unisba.

International Coffee Organization. (2014). Historical data. (http:/ / www.ico.org/ new_historical.asp?section=Statistics) diunduh pada 22 September 2014

International Finance Corporation (IFC). (2011). Consultant for mentoring coffee farmer logbook and data collection in North Sumatra. Hasil survei tidak dipublikasikan.

Mulyoutami, E., Stefanus, E., Schalenbourg, W., Rahayu, S., dan J oshi, L. (2004). Pengetahuan lokal petani dan inovasi ekologi dalam konservasi dan pengolahan tanah pada pertanian berbasis kopi di Sumberjaya, Lampung Barat, J urnal Agrivita Vol. 26, No. 1, pp. 98-107.

Moreira, C.F.; Fernandes, E.D.N., and Tagliaferro, F.S. (2008). Shaded coffee: a way to increase sustainability in Brazilian organic coffee plantations, 16 th IFOAM Organic World Congress, M odena, Italy, J une 16-20, 2008. (http:/ / orgprints.org/ 12399) diunduh pada 17 Maret 2012

Mawardi, S., Hulupi, R., Wibawa, A., Wiryadiputra, S., dan Yusianto. (2008). Panduan budidaya dan pengolahan kopi arabika Gayo, Pusat Penelitian Kopi dan Kakao Indonesia, APED, Bappeda NAD dan UNDP.

Kementerian Pertanian RI. (2010). Pedoman umum pelaksanaan pengembangan/ rehabilitasi kopi organik (specialty) tahun 2010. Kementerian Pertanian RI.

Kementerian Pertanian RI. (2014). Basis data statistik pertanian. (http:/ / aplikasi.pertanian.go.id/ bdsp/ newkom.asp) diunduh pada 22 September 2014

Prasmatiwi, F. E., Irham, Suryantini, A., dan J amhari. (2010). Analisis keberlanjutan usahatani kopi di kawasan hutan Kabupaten Lampung Barat dengan pendekatan nilai ekonomi lingkungan, Pelita Perkebunan Vol. 26, No. 1, pp. 57-69.

Rice, R. (2010). The ecological benefits of shade-grown coffee: The case for going Bird Friendly ${ }^{\circledR}$, Washington: Smithsonian Migratory Bird Center (SMBC)-National Zoological Park.

Saragih, J .R. (2012a). M odel pengembangan ekonomi lokal (PEL) berbasis produktivitas kopi arabika spesialti di Kabupaten Simalungun. Wahana Hijau J urnal Perencanaan dan Pengembangan Wilayah Vol. 7, No. 3, pp. $117-125$.

Saragih, J .R. (2012b). Pengaruh faktor sosial ekonomi dan ekologi terhadap produksi kopi arabika spesiati dalam pengembangan ekonomi lokal di Kabupaten Simalungun, Disertasi Doktor, Sekolah Pascasarjana Universitas Sumatera Utara, Medan.

Saragih, J .R. (2013). Socioeconomic and ecological dimension of certified and conventional arabica coffee production in North Sumatra, Indonesia, Asian J ournal of Agriculture and Rural Development Vol. 3, No. 3, pp. 93-107.

Soto-Pinto, L., Perfecto, I., Hernandez, J.C., and Nieto, J.C. (2000). Shade effect on coffee production at the northern Tzeltal zone of the state of Chiapas, M exico, Agriculture, Ecosystems \& Environment Vol. 80, No. 1-2, pp. 61-69.

Verbist, B., Putra, A.E., dan Budidarsono, S. (2004). Penyebab alih guna lahan dan akibatnya terhadap fungsi Daerah Aliran Sungai (DAS) pada lansekap agroforestri berbasis kopi di Sumatera, J urnal Agrivita Vol. 26, No. 1, pp. 29-38 .

Vossen, H. A. M. V. (2005). A critical analysis of the agronomic and economic sustainability of organic coffee production. Experimental Agriculture Vol. 41, pp. 449-473.

Winaryo, Nur, A.M., dan Soenaryo. (1987). Regenerasi dan pertumbuhan kopi robusta berbatang ganda pada berbagai kerapatan penaung, Pelita Perkebunan Vol. 3, No. 3, pp. 91-95.

Winata, A. dan Yuliana, E. (2012). Tingkat partisipasi petani hutan dalam Program Pengelolaan Hutan Bersama M asyarakat (PHBM) Perhutani, M IM BAR: J urnal Sosial dan Pembangunan, Vol. XXVIII, No. 1, pp. 65-76, Bandung: P2U LPPM Unisba. 
Yadessa, A., Burkhardt, J ., Denich, M., Gole, T.w., Bekele, B., and Goldbach, H. (2008). Effect of different indigenous shade trees on quality of wild arabika coffee in the Afromontane rainforest of Ethiopia, Poster presented at 22 $2^{\text {nd }}$ International Conference on Coffee Science (ASIC), Campinas-Brazil. (http:/ / www.asic-cafe.org/ pdf/ abstract/ PA544_2008.pdf) diunduh pada 17 Maret 2012

Zaenudin. (2009). Good agricultural practices and sustainable coffee production. Module Training of Trainers Course, M edan: International Finance Corporation/ IFC and PT. Indo Cafco. 